\title{
POLITYKA RZECZYPOSPOLITEJ WOBEC MOSKWY W LATACH 1672-1699
}

\author{
Artur Kijas \\ Uniwersytet im. Adama Mickiewicza w Poznaniu
}

\author{
ABSTRACT \\ THE POLICY OF THE POLISH-LITHUANIAN COMMONWEALTH \\ TOWARDS MOSCOW, 1672-1699
}

A fundamental transformation of the Polish-Russian relationship occurred in the second half of the $17^{\text {th }}$ century. The war begun in 1654 ended in 1667 with the Truce of Andrusovo, when the palatinates of Smolensk, Chernihiv and the Left-Bank Ukraine were ceded to Moscow. Andrusovo represented a major turning point in the Polish-Russian relationship. Not only did the Commonwealth irretrievably lose its eastern lands, but the outcome confirmed the Russian ascendancy in the field of bilateral relations. The danger from the Ottoman Empire and the Crimean Khanate to Central and Eastern Europe led to Russia becoming a major member of the anti-Turkish coalition. The issue of an alliance with Russia against Turkey became of particular relevance during the reign of John III Sobieski. This occasioned negotiations on the subject of a permanent peace treaty between the Commonwealth and Russia which were combined with an attempt to recover diplomatically at least some of the lost lands. Krzysztof Grzymułtowski represented the Polish side in the final stage of arduous negotiations. The treaty of 1686 closed the chapter of Polish-Russian military confrontations, with a political degradation of the Commonwealth as their ultimate result.

Keywords: Commonwealth's eastern policy, Andrusovo, John III Sobieski, Ottoman threat, military alliance with Russia, permanent peace treaty.

Słowa kluczowe: polityka wschodnia Rzeczypospolitej, Andruszów, Jan III Sobieski, zagrożenie tureckie, sojusz wojskowy z Rosją, pokój wieczysty.

W nocy z 29 na 30 stycznia 1676 roku, w wieku 47 lat, zmarł nieoczekiwanie car Aleksy Michajłowicz, drugi przedstawiciel dynastii Romanowów, która w samej Rosji, jak i na arenie międzynarodowej powoli umacniała swoją obecność i prestiż. W okresie rządów trwających blisko 31 lat udało mu się przezwyciężyć kryzys, odbudować autorytet władzy carskiej. Na czas jego rządów przypadły wojny 
z Rzecząpospolitą Obojga Narodów, Szwecją i Turcją. Polityka wewnętrzna cara i jego otoczenia przyczyniła się do buntów: Miedzianego i Solnego. Do wystąpień czerni i ludzi posadzkich doszło w Solwyczegodsku, Ustiugu, Kursku, Woroneżu, Nowogrodzie Wielkim, Pskowie i na peryferiach państwa. Pod koniec jego panowania wybuchło groźne powstanie Stiepana Razina. Na jakiś czas Rosja uwikłana została również w wielki spór ideologiczny wywołany reformą Cerkwi patriarchy Nikona. Okres rządów Aleksego Michajłowicza historiografia rosyjska oceniała jednak pozytywnie. Podkreślano, że pozostawił kraj uporządkowany pod względem prawnym i administracyjnym, znacznie powiększony terytorialnie, otwierający się powoli ku zachodowi Europy.

W okresie panowania tego władcy istotnej zmianie uległy stosunki polsko-rosyjskie. Decyzja Soboru Ziemskiego z 1653 roku o przyłączeniu Ukrainy do Rosji (województwa bracławskiego, czernihowskiego i kijowskiego), formalnie zatwierdzona na radzie kozackiej w Perejasławiu 18 stycznia 1654 roku, oznaczała złamanie pokoju wieczystego zawartego z Polską w 1634 roku. Była ona przyczyną wojny polsko-rosyjskiej, która przez trzynaście lat, od 1654 roku, mocno absorbowała zarówno jedną, jak i drugą stronę. Celem Rosji były Smoleńsk, Siewierszczyzna z Czernihowem ,[...] słowem wszystkie zamki i ziemie, które odpadły od Moskwy za dni Zygmunta III i Władysława IV". Wojna przerwana 3 listopada 1656 roku rozejmem w Niemieży pod Wilnem wznowiona została w 1658 roku. Wspomniany rozejm, podpisany w trakcie wojny Rzeczypospolitej ze Szwecją, przewidywał po raz pierwszy w historii wzajemnych relacji pewne ustępstwa ze strony polskiej na rzecz Rosji. Jan Kazimierz podkreślał, że pokój z Moskwą ,[...] potrzebniejszy rozumiemy niż ze Szwedami i zawrzeć go koniecznie chcemy". Na mocy rozejmu obie układające się strony zobowiązały się współdziałać w wojnie przeciw Szwecji. Zgodzono się także, aby po śmierci Jana Kazimierza odbyła się elekcja cara na tron Polski, który po objęciu rządów miał podpisać pakta konwenta i kontynuować dotychczasową politykę zagraniczną państwa polsko-litewskiego. Słusznie jednak zauważono, że poza sojuszem wojskowym zbyt wiele było spraw, które dzieliły oba państwa, aby rozejm mógł przetrwać dłużej.

Mimo że Aleksy Michajłowicz, wznawiając wojnę z Polską, robił wszystko, aby w zmaganiach z Rzecząpospolitą zapewnić sobie zwycięstwo, nie dążył do nadmiernego osłabienia państwa polsko-litewskiego. Obawiając się zarówno Szwecji, jak i Turcji, liczył się z możliwością aliansu i polubownego załatwienia trudnych i spornych kwestii. W Rzeczypospolitej sojusznika Rosji widzieli także bliscy współpracownicy cara Aleksego, jak na przykład pochodzący z Pskowa kierownik prikazu poselskiego Atanazy Ordin-Naszczokin, najwybitniejszy rosyjski mąż stanu epoki przedpiotrowej. Przewodniczył on „,wielkiemu poselstwu”, które w latach 1662-1663 przebywało w Polsce i prowadziło rozmowy z królewskimi dyplomatami. Ich apogeum przypadło na spotkanie stron we Lwowie w 1663 roku. Choć długie, kontrowersyjne rozmowy nie przyniosły żadnych poważniejszych decyzji, Zbigniew Wójcik nie traktował ich jako bezowocnych, uznając, że stanowiły istotny etap $\mathrm{w}$ dalszych rokowaniach. W pismach ulotnych przeciągające się negocjacje nazywano natomiast „,bezsensownymi”, prowadzonymi przez „niemądre głowy”. 
Postanowiła wykorzystać je strona polska. Próba siłowego rozstrzygnięcia przez Rzeczpospolitą kwestii ukraińskiej zakończyła się jednak niepowodzeniem. Wyprawa Jana Kazimierza na Zadnieprze na przełomie lat 1663 i 1664 nie przyniosła spodziewanych sukcesów. Planowano wówczas nie tylko zajęcie lewobrzeżnej Ukrainy, ale także uderzenie $\mathrm{w}$ głąb posiadłości rosyjskich, z zajęciem Moskwy włącznie, oraz podyktowanie carowi korzystnego dla Rzeczypospolitej pokoju. Z pomocą Aleksemu przyszli Kozacy. Na lewobrzeżnej Ukrainie umocniła się pozycja hetmana Iwana Brzuchowieckiego, zaufanego cara. Podział Ukrainy na dwie części, nieuznawany przez stronę polską, pozostał faktem. Tatarzy krymscy, na których pomoc liczono, zawiedli. Możliwość zbrojnego pokonania Rosji w obliczu trudności wewnętrznych - wybuchu rokoszu Jerzego Sebastiana Lubomirskiego - stała się niemożliwa. Zmusiło to Jana Kazimierza do powrotu do negocjacji. Zaakceptowała to strona rosyjska, której w końcowej fazie rozmów przewodniczył ponownie Ordin-Naszczokin. 30 stycznia 1667 roku, po długich pertraktacjach w Andruszowie, na 13,5 roku podpisano traktat rozejmowy, nazywany „pokojem doczesnym”. Na mocy jego postanowień w ręce rosyjskie przeszły ziemie: smoleńska, czernihowsko-siewierska i Zadnieprze z prawobrzeżnej Ukrainy. Kijów wraz z powiatem formalnie tylko, przez dwa lata, miał pozostawać we władaniu Rosji, a po tym czasie 15 kwietnia 1669 roku powinien być zwrócony Polsce. Wówczas miała się zebrać nowa komisja polsko-rosyjska i rozpocząć rokowania o przekształcenie rozejmu w pokój wieczysty. Praktycznie jednak Kijów pozostał rosyjskim kilka wieków.

W rozejmie andruszowskim przewidziano także wspólne wystąpienie przeciw Turcji oraz gwarancje dla katolików w Rosji i prawosławnych w Polsce. Magnatom i szlachcie polskiej, która utraciła swoje posiadłości na Zadnieprzu, Aleksy Michajłowicz zobowiązał się wypłacić milion złotych polskich w dobrej monecie. Rekompensata dotyczyła również Sobieskich, których dobra przeszły w ręce Rosji.

$\mathrm{Na}$ mocy traktatu rozejmowego Zaporoże zostało uznane za kondominium Polski i Rosji. Gdyby doszło do agresji Tatarów lub Turcji, zamieszkujący ten obszar Kozacy mieli służyć królowi polskiemu i carowi moskiewskiemu. Polsko-rosyjskie przymierze wojskowe, mimo zastrzeżeń, że nabierze ono mocy dopiero, gdy sułtan turecki i chan krymski odrzucą ofiarowaną przyjaźń władców Rzeczypospolitej i Rosji, było jedynym plusem podpisanego traktatu. Jednak już wkrótce miało się okazać, że zapis dotyczący układu wojskowego był zbyt ogólny.

Zawarcie traktatu andruszowskiego nie spotkało się z aprobatą ze strony szlachty. Niektóre sejmiki, licząc na pomoc wojskową w wojnie z Turcją, opowiedziały się za umocnieniem rozejmu z Rosją. Sejmik łomżyński, dla przykładu, krytycznie nastawiony do Porty, proponował utrzymanie zapisanych w traktacie zobowiązań. Odmienne stanowisko zajął sejmik różański. Według zgromadzonych na nim przedstawicieli szlachty Moskwicin ,[... ] nigdy nam pakt nie dotrzymuje i nie można mu ufać". Ponadto niezadowoleni byli egzulanci, którzy po utracie posiadłości na rzecz Rosji znaleźli się w trudnej sytuacji życiowej. W niewygodnym położeniu, w jakim była wówczas Polska po niszczących wojnach ze Szwecją i Rosją, niełatwo było jednak o coś więcej. Trudno się zatem nie zgodzić z opinią Zbigniewa Wójcika, nieomal sprzed pół wieku, że w styczniu 1667 roku Rzeczpospolita „,...] osiągnęła przy stole 
obrad niewątpliwie wszystko, co mogła podówczas osiągnąć, biorąc pod uwagę jej aktualną sytuację wewnętrzną i międzynarodową".

Dla Rzeczypospolitej Andruszów oznaczał załamanie się mocarstwowości, a także klęskę w jej polityce wschodniej. Począwszy od daty podpisania rozejmu, olbrzymie obszary wschodnie zamieszkałe przez ludność niepolską, w większości prawosławną, stopniowo odpadały od państwa polsko-litewskiego. W następstwie traktatu Rzeczpospolita wyeliminowana została z rywalizacji o przewagę w Europie Północno-Wschodniej. Abdykacja Jana Kazimierza 16 września 1668 roku zamknęła okres burzliwych wydarzeń, które przyniosły Rosji znaczny sukces w zmaganiach ze swym zachodnim sąsiadem.

Elekcja nowego władcy w trudnej sytuacji zarówno wewnętrznej, jak i zewnętrznej miała niezwykle burzliwy przebieg. Wśród pretendentów do tronu polskiego pojawiło się kilku kandydatów, między innymi zgłoszony przez stronę rosyjską najstarszy żyjący syn cara Aleksego Michajłowicza - Aleksy. Poselstwa rosyjskie w latach 1667-1669 podróżujące po dworach europejskich (Wiedeń, Madryt, Paryż) świadczą o tym, że w Moskwie kandydaturę tę traktowano poważnie. W Polsce nie wzbudziła ona jednak większego entuzjazmu. „Gdyby Moskal został królem polskim - pisał młody Gottfried Wilhelm Leibniz - czyż możemy pomyśleć, że inni chrześcijanie będą siedzieli spokojnie z założonymi rękami?... Otworzy się droga dla barbarzyńców aż do wnętrza Europy".

Wybór na króla Michała Korybuta Wiśniowieckiego w czerwcu 1669 roku nie przyniósł zmian w relacjach polsko-rosyjskich. Waśnie wewnętrzne, opozycja antykrólewska sprzyjały natomiast umocnieniu rządów rosyjskich na lewobrzeżnej Ukrainie. Odnowiony z Rosją w 1670 roku rozejm okupiony został pozostaniem Kijowa w rękach carskich. W 1672 roku Wiśniowiecki uzyskał co prawda iluzoryczną obietnicę pomocy Rosji w wojnie $\mathrm{z}$ Turcją, ale za cenę potwierdzenia postanowień traktatu andruszowskiego. Rosja ograniczyła swoją postawę do ostrzeżenia Stambułu, że atak na Rzeczpospolitą przyniesie przeciwdziałanie wojsk rosyjskich, czego jednak z powodu wewnętrznych trudności tego państwa na dworze sułtańskim nie odbierano na serio.

Prohabsburska polityka Michała Korybuta Wiśniowieckiego doprowadziła w ostateczności do wojny z Turcją, w której trakcie wojska sułtana Mehmeda IV i wspierające go siły chana krymskiego Selim Gireja zdobyły Kamieniec Podolski, zajęły Podole oraz prawobrzeżną Ukrainę. Zdobycze tureckie ugruntowane zostały haniebnym traktatem w Buczaczu 18 października 1672 roku. Śmierć króla 10 września 1673 roku, w przeddzień zwycięstwa nad Turkami pod Chocimiem, przyniosła koronę królewską pogromcy paszy Huseina - Janowi Sobieskiemu. Dzięki sukcesom odniesionym w walkach z Turkami, talentowi dowódczemu i bogatej osobowości 19 maja 1674 roku został on obrany królem Polski. Na tronie, jak pisał Władysław Konopczyński, zasiadł ,[...] człowiek wyższy nad całą generację, aczkolwiek nie wyprzedzający epoki [...] każdy musi przyznać, że godniejszego Piasta nie mogła Rzeczpospolita wyszukać w 1674 roku”.

Na panowanie Sobieskiego w Polsce przypadają ostatnie lata rządów Aleksego Michajłowicza w Rosji (zmarł 29 stycznia 1676 roku), a później jego dzieci 
- Fiodora Aleksiejewicza, regentki Sofii Aleksiejewnej, Iwana Aleksiejewicza i syna z drugiego małżeństwa Aleksego - Piotra Aleksiejewicza. Normalizacja stosunków z Rosją w założeniach Sobieskiego miała przynieść Rzeczypospolitej wzmocnienie koalicji antytureckiej oraz odzyskanie utraconych wcześniej terytoriów, zwłaszcza lewobrzeżnej Ukrainy i Podola. Nie zwlekając zbyt długo, jesienią 1674 roku król zdecydował się na wznowienie działań wojennych z Portą. Liczył mocno na współdziałanie z Rosją. Wiadomość przekazana przez rezydenta polskiego w Moskwie, Pawła Świderskiego, jakoby car ruszył na wojnę z Turkami, okazała się jednakże nieprawdziwa. Poza zdobyciem Baru i Bracławia oraz kilku drobnych obozów nieprzyjaciela Sobieskiemu nie udało się rozbić większych sił tureckich, które wycofały się za Dniestr. W gronie polityków rosyjskich zabrakło wówczas Ordina-Naszczokina, zwolennika polsko-rosyjskiej współpracy, który wielokrotnie, jak to wspomina w swoim diariuszu Jan Antoni Chrapowicki, nawoływał obie strony do współdziałania. Carska niełaska, która go spotkała w 1671 roku, spowodowała, że został pozbawiony funkcji kierownika prikazu poselskiego i zamknięty w krynieckim eremie w pobliżu Pskowa jako starzec Antoni. Ponownie do jego bogatych dyplomatycznych doświadczeń odwołał się dopiero Fiodor Aleksiejewicz, kiedy zaproszony został do Moskwy w czasie negocjacji dotyczących przedłużenia traktatu andruszowskiego.

Polityka rosyjska wobec Rzeczypospolitej wypracowana w czasach Aleksego Michajłowicza kontynuowana była przez jego syna Fiodora Aleksiejewicza, który w chwili śmierci ojca liczył zaledwie 14,5 roku. Podobnie jak jego siostra Sofia znał on język polski i łacinę - dzięki swemu nauczycielowi pochodzącemu z Białorusi Symeonowi Połockiemu, związanemu z Akademią Kijowsko-Mohylańską, jedyną wyższą uczelnią we Wschodniej Europie. Brak politycznych doświadczeń nie przeszkodził Fiodorowi w prowadzeniu konsekwentnej polityki polegającej na przedłużaniu na krótkie okresy rozejmu bez konkretnych obietnic co do bliskiej współpracy. O zwrocie Polsce Siewierszczyzny, Smoleńska i lewobrzeżnej Ukrainy posłowie rosyjscy wysyłani przez cara z Moskwy nie chcieli rozmawiać. Posłów Sobieskiego negocjujących w Moskwie zbywano nic nieznaczącymi obietnicami lub też niewielkimi ustępstwami. Tak było w 1678 roku w trakcie rozmów z wysłanymi do cara Fiodora „wielkimi posłami”, przedstawicielami Korony - wojewodą wołyńskim Michałem Czartoryskim i reprezentującym Wielkie Księstwo Litewskie Kazimierzem Janem Sapiehą. Podobna sytuacja powtórzyła się w trakcie poselstwa Cypriana Pawła Brzostowskiego w Moskwie w 1679 roku. W czasie rozmów w sierpniu 1678 roku, mających na celu przedłużenie traktatu andruszowskiego o dalsze 13 lat, Rzeczpospolita zgodziła się na pozostawienie Kijowa w rękach rosyjskich. Rosja miała zapłacić za to 200000 rubli (około miliona złotych polskich), a także przekazać Polsce miasta na północnym wschodzie - Newel, Siebież i Wieliż.

Niekończące się nieporozumienia i swary towarzyszyły również pobytowi posłów rosyjskich w Polsce. Tak było w kwietniu 1678 roku w Lublinie, gdzie do przebywającego tam Sobieskiego przybyli wysłannicy carscy - Iwan Czaadajew i Jemielian Ukraincew. Sobieski miał nadzieję na zawarcie z Rosją pokoju wieczystego, lecz do rozmów na ten temat Rosjanie nie zostali upoważnieni. Przybyli jedynie po to, aby rozejm z Rzecząpospolitą przedłużyć na dalsze dwa lata. W trakcie rozmów doszło 
też do przykrego incydentu. Posłowie Fiodora zażądali usunięcia z Zamku Królewskiego w Warszawie obrazów gloryfikujących zwycięstwo Stanisława Żółkiewskiego pod Kłuszynem oraz ukazujących wziętych do niewoli cara Wasyla Szujskiego i jego braci. Wywołało to ostry sprzeciw króla $i$ hetmana polnego koronnego Stanisława Jabłonowskiego. Groziło nawet zerwaniem rozmów z Rosją i przeorientowaniem polskiej polityki zagranicznej. Mimo nieporozumień i napięć powrócono jednak do rozmów. Priorytetową dla Sobieskiego kwestią pozostawała bowiem sprawa pokoju wieczystego i wspólne wystąpienie przeciwko Turkom i Tatarom.

Na sejm grodzieński 1678/1679 roku przybyło poselstwo rosyjskie z Iwanem Buturlinem i Iwanem Czaadajewem. W trakcie rozmów strona polska zaproponowała warunki nie do przyjęcia dla Rosjan. Dotyczyły one zwrotu wszystkich ziem utraconych przez Rzeczpospolitą na mocy rozejmu andruszowskiego, corocznych subsydiów w wysokości 600000 rubli na prowadzenie wojny oraz osobistego udziału cara w wyprawie przeciwko Turkom. Choć później suma subsydiów obniżona została do 200 000, propozycje odrzucono. Druga misja Buturlina i Czaadajewa w Polsce w 1680 roku, mimo że podjęła problem współpracy wojskowej, uzależniała ją od ataku ze strony Turcji. Dobry klimat początkowo towarzyszący rozmowom popsuła kwestia prześladowania wyznawców prawosławia w Polsce, podniesiona przez posłów rosyjskich, co rzekomo mocno niepokoiło bogobojnego cara Fiodora.

Mimo niepowodzeń polskich wysiłków dyplomatycznych i podpisania przez Rosję 3 (13) stycznia 1681 roku traktatu pokojowego z Portą w Bakczysaraju Sobieski nie zaprzestał działań na rzecz koalicji antytureckiej. Jednakże polityka króla zakładająca na początku lat 80 . XVII wieku wspólne z Rosją spacyfikowanie Porty poniosła fiasko. Powrotowi do aktywniejszej polityki wschodniej po śmierci cara Fiodora 27 kwietnia (7 maja) 1682 roku nie sprzyjała sytuacja wewnętrzna Rosji. Ogłoszenie następcą tronu dziesięcioletniego Piotra, syna cara Aleksego i Natalii Naryszkiny, pociągnęło za sobą destabilizację państwa. Rywalizacja Miłosławskich z Naryszkinami, regencja ambitnej Sofii wspieranej przez Wasyla Golicyna, bunt strzelców osłabiły aktywność Rosji na zewnątrz. Dopiero późną jesienią 1683 roku (po zwycięstwie Jana III pod Wiedniem) rozpoczęły się rokowania nowej komisji polsko-rosyjskiej w Andruszowie. Ze strony polskiej przewodniczył im główny komisarz królewski, wojewoda poznański Krzysztof Grzymułtowski. Z wcześniejszych kontaktów z posłańcami rosyjskimi wyniósł on raczej negatywne wrażenia. Traktował Rosję jako państwo wiarołomne, niedotrzymujące podpisanych porozumień. W konkluzji swego memoriału przygotowanego dla króla konstatował jednak, że w zaistniałej sytuacji współpraca z Rosją jest niezbędna. Bez udziału Rosji w koalicji antytureckiej także Sobieski nie wyobrażał sobie kontynuacji wojny z Portą. Uczestniczący w rozmowach Wasyl Golicyn, faworyt Sofii i faktyczny kierownik prikazu poselskiego, jako warunek sine qua non porozumienia stawiał oddanie Rosji na zawsze Kijowa i zdobyczy z wojny z lat 1654-1667. Instrukcja dla delegacji rosyjskiej na rokowania ze stroną polsko-litewską uzasadniała zatrzymanie przez Rosję, wbrew postanowieniom traktatu andruszowskiego, Kijowa. Przewidywała ona, że zawarcie pokoju z Rzecząpospolitą może nastąpić, pod warunkiem ,[...] że prawa Carskiej 
Mości do wszystkich zdobytych miast i ziem będą wieczyste i tak jak teraz obaj wielcy władcy nasi mają swoje państwa pod swoją władzą, tak na wieczność będzie”.

Za porozumieniem z Rosją optowali dyplomaci papiescy i wysłannicy cesarza Leopolda I. Mimo dobrych chęci ze strony polskiej komisja andruszowska zakończyła się fiaskiem. Po ponad dwóch latach z inicjatywy Sobieskiego wznowiono rozmowy. Pewien wpływ na normalizację stosunków polsko-rosyjskich miała postawa dworu cesarskiego i Stolicy Apostolskiej zainteresowanych przystąpieniem Rosji do koalicji antyosmańskiej. Nieomal równocześnie z powołaniem Ligi Świętej pod egidą papieża Innocentego XI do Moskwy wysłane zostało poselstwo od cesarza Leopolda I, aby zachęcić władze rosyjskie do włączenia się do wojny z Imperium Osmańskim i Chanatem Krymskim. Nieodzownym warunkiem sojuszu był pokój między Rzecząpospolitą i Rosją. Decyzja o wysłaniu do Moskwy poselstwa z Krzysztofem Grzymułtowskim na czele została przyjęta przez sejm w 1685 roku. Podjęto ją na tajnej radzie senatu po trudnych negocjacjach z udziałem dworu królewskiego i opozycji, przy czynnym pośrednictwie nuncjusza papieskiego Opizio Pallaviciniego. Przystąpienie do rozmów na temat pokoju wieczystego oznaczało przyjęcie przez Rzeczpospolitą warunków stawianych przez Moskwę, która uparcie i konsekwentnie wychodziła z założenia, że wszystko, co zostało zdobyte przez Aleksego Michajłowicza, stanowi własność rosyjską. Do Moskwy w składzie wielkiego poselstwa od króla i Rzeczypospolitej przybyli wówczas: z Korony wspomniany już Grzymułtowski, a z Litwy kanclerz wielki koronny Marcjan Ogiński. W skład poselstwa wchodzili ponadto: podstoli koronny Aleksander Przyjemski, kasztelan kamieniecki Jan Potocki i inni. Stronę rosyjską, oprócz Wasyla Golicyna i Iwana Czaadajewa, reprezentował Borys Starszy Szeremietiew, który doświadczenia wojskowe zdobywał w wyprawach na twierdze tureckie u ujścia Dniestru. Rokowania, jak nieomal wszystkie poprzednie, były trudne. Tymczasem król oczekiwał pozytywnych ich rezultatów. Negocjacje przeciągały się nie tylko z powodu stanowiska Grzymułtowskiego, który zgodnie z zaleceniami króla dążył do tego, aby straty Rzeczypospolitej były jak najmniejsze. W rokowaniach szczególną rolę odgrywała także strona litewska, reprezentowana przez Ogińskiego. W literaturze spotyka się opinię, że Litwini poprzez swoje votum separatum dostarczali często argumentów stronie rosyjskiej. Było to podyktowane nie tylko bliskim sąsiedztwem Wielkiego Księstwa Litewskiego z Rosją, chęcią zabezpieczenia granic, ale i lepszą znajomością przez nich Rosjan, ich języka, charakteru i kultury. Pokój wieczysty dla magnaterii, szlachty i mieszczan litewskich stwarzał możliwości odbudowy obiektów zniszczonych w czasie wyprawy Aleksego Michajłowicza na Litwę w 1655 roku i nawiązania z Rosją kontaktów gospodarczych. Pozostawała również sprawa egzulantów, którzy w czasie wojen polsko-rosyjskich utracili swoje dobra na wschodzie.

Mimo wielu kontrowersji 23 kwietnia (3 maja) 1686 roku uzgodniono ostatecznie warunki wieczystego pokoju, który stał się podstawą podpisanego trzy dni później traktatu pokojowego. Za przymierze z Rosją skierowane przeciwko Turkom i Tatarom i niezbyt wysoką subwencję pieniężną, 146000 rubli (730 000 złotych polskich), przyszło zapłacić Rzeczypospolitej drogo. Zrzekała się ostatecznie Smoleńszczyzny, Czernihowszczyzny, Dorohobuża i Staroduba, a także Kijowa, „prarodzicielskiej 
ojcowizny Ich Carskiej Mości”, wraz z ziemiami między rzeką Irpeń a Stugną, z miasteczkami Wasylków, Stajki i Trypol, które stały się częścią państwa rosyjskiego. Rosja przejęła pełną władzę nad Zaporożem kontrolowanym dotąd wspólnie. Stała się nadto gwarantem wolności wyznania prawosławnych w Rzeczypospolitej z prawem opieki nad nimi. Naruszało to niezależność państwową i stwarzało podstawy do carskiej ingerencji w wewnętrzne sprawy Polski. Podpisanie wieczystego pokoju z Rosją było klęską polskiej polityki wschodniej.

Ratunkiem pozwalającym na zapobieżenie niefortunnym następstwom traktatu miało być zajęcie Mołdawii i Wołoszczyzny, unieszkodliwienie Tatarów oraz przywrócenie wpływów polskich na Węgrzech. Wyprawa na Mołdawię powiązana była ściśle z planami dynastycznymi króla i królowej Marii Kazimiery. Chodziło o zdobycie tronu mołdawskiego dla syna Jakuba. W sierpniu 1686 roku Jan III Sobieski wkroczył do Jass. Jako zbawca chrześcijaństwa uroczyście powitany został przez metropolitę Dosofteia (Dosyteusza). Wyprawa królewska nie przyniosła jednak spodziewanych rezultatów. Podpalenie przez Tatarów stepów spowodowało odwrót armii polskiego króla. $Z$ całej Mołdawii utrzymali Polacy niewielki pograniczny skrawek - okręg czerniowiecki i twierdzę Soroka. Należało więc powrócić do smutnej rzeczywistości związanej z ratyfikacją wieczystego pokoju. Nic zatem dziwnego, że Sobieski przez blisko pół roku zwlekał ze złożeniem pod traktatem swojego podpisu. Dokument podpisał dopiero 21 grudnia 1686 roku we Lwowie w obecności wielkiego poselstwa rosyjskiego z Piotrem Starszym Szeremietiewem na czele. Również kolejna kampania mołdawska Sobieskiego z sierpnia 1691 roku zakończyła się niepowodzeniem.

Silna opozycja antykrólewska, ambicje hetmana wielkiego koronnego Stanisława Jana Jabłonowskiego, marzącego o koronie po Janie III, wreszcie plany dynastyczne Sobieskiego przy utrzymującym się zagrożeniu ze strony Porty musiały mieć wpływ na relacje polsko-rosyjskie. Dostrzegali je zapewne dość często posłujący do Polski w okresie panowania Sobieskiego dyplomaci moskiewscy. Mimo wstrząsów, które przeżyła Rosja po śmierci Fiodora Aleksiejewicza, w okresie rządów regentki Sofii Aleksiejewny i jej faworyta Borysa Golicyna udało się Rosji zachować status quo z sąsiadami. Dzięki potwierdzeniu istniejących rozejmów nastąpiło nawet wzmocnienie jej pozycji na prawobrzeżnej Ukrainie.

Stosunki polsko-rosyjskie w okresie rządów Jana III Sobieskiego przypadały nie tylko na czas osłabienia władzy centralnej oraz aparatu państwowego, dużo większego w Rzeczypospolitej niż w Rosji, ale też upadku opartej na szlacheckim pospolitym ruszeniu wojskowości. W odniesieniu do Rosji był to proces, jak zauważył Kirył Koczegarow, krótkotrwały, dla Rzeczypospolitej dużo głębszy. W niezrealizowanym projekcie reform cara Fiodora Aleksiejewicza, do których nawiązał Piotr I, było utworzenie stałej armii poprzez powołanie do wojska przedstawicieli wszystkich stanów.

Choć traktat o pokoju wieczystym był dużym sukcesem dyplomatycznym Sofii Aleksiejewny, nie przyniósł oczekiwanej współpracy polsko-rosyjskiej. Mimo zapewnień strony rosyjskiej wzajemne relacje po wyjeździe Grzymułtowskiego nie uległy zmianie. Rezydent polski w Moskwie Jerzy Dominik Dowmont miał duże 
trudności w wyegzekwowaniu od Rosjan zobowiązań przyrzeczonego aliansu wojskowego.

Warunki pokoju wieczystego, choć przewidywały wspólne wystąpienie, by „,[...] chwałę mahometańskiego ohydztwa zniszczyć", nie zakładały udzielenia znacznej pomocy Polsce ze strony Rosji, na co mocno w Warszawie liczono. Nie wszystko zatem, co zostało zapisane w traktacie o wieczystym pokoju, zostało wypełnione. Samotne wyprawy Wasyla Golicyna na Krym w 1687 i 1689 roku, zakończone niepowodzeniem, przyczyniły się do utraty pozycji przez Sofię. W konfrontacji ze swoim przyrodnim bratem Piotrem poniosła klęskę. Późniejsze zwycięstwo Piotra w wojnie z Turcją pod Azowem (w 1696 roku) spowodowało, że Rosja jako pełnoprawny członek weszła do Ligi Świętej. O ile pierwsze starcie rosyjsko-tureckie zakończone traktatem bakczysarajskim było odparciem ataku tureckiego, o tyle drugie, do którego doszło w latach 1695-1696, stanowiło początek długoletnich zmagań z Imperium Ottomańskim. Pokój w Stambule podpisany na trzydzieści lat w lipcu 1700 roku przez dyplomatę rosyjskiego Jemieliana Ukraincewa, znanego wcześniej z pertraktacji z Polską, po utracie przez Golicyna stanowiska kierownika prikazu poselskiego spowodował przejście Azowa pod władzę Rosji oraz zaprzestanie płacenia daniny chanowi tatarskiemu.

Śmierć Sobieskiego 17 czerwca 1696 roku zamyka blisko 22-letni okres jego panowania i walki o wzmocnienie pozycji Rzeczypospolitej w Europie. Mimo wysiłków nie udało mu się rewindykować ziem utraconych na rzecz Rosji na mocy traktatu andruszowskiego ani też pozyskać Rosji do koalicji antytureckiej. Nie sprzyjała temu sytuacja wewnętrzna Polski. Zbyt dobrze orientowano się w Moskwie w licznych słabościach Rzeczypospolitej. Powodowało to, że relacje polsko-rosyjskie nie były symetryczne. Nie można jednak nie dostrzec także pewnej nieufności, a nawet wrogości, jaką przejawiały władze Rosji wobec Polski. Być może ich źródła należy szukać również w upokorzeniu, jakiego dynastia Romanowów doznała na początku swego panowania od Zygmunta III Wazy.

Pokój i przymierze Rzeczypospolitej z Rosją, konstatuje Koczegarow, stały się możliwe po blisko 20 latach trudnych pertraktacji, kiedy negocjujące strony potrafiły ostatecznie, choć tylko częściowo, pogodzić nagromadzone sprzeczności i rozbieżności. W Moskwie przyjęto je jako wielki polityczny sukces. W Polsce natomiast wywołały rozczarowanie i niezadowolenie $\mathrm{z}$ powodu na zawsze utraconych ziem na wschodzie.

Mimo wielkich wysiłków Janowi III Sobieskiemu nie udało się zrealizować ambitnych planów pokonania Turków i odzyskania utraconych terytoriów od Rosji i Turcji. Odpowiedzialnością za niepowodzenia w polskiej polityce wschodniej trudno jednakże obarczać króla. Były one następstwem słabości Rzeczypospolitej, z którą w końcu XVII wieku przestali się liczyć sąsiedzi. 


\section{BIBLIOGRAFIA}

\section{Źródła}

Chrapowicki J.A., Diariusz, cz. I: lata 1656-1664, opr. i wstępem poprzedził T. Wasilewski, Warszawa 1978; cz. II: lata 1665-1669, opr. i wstępem opatrzyli A. Rachuba, T. Wasilewski, Warszawa 1988; cz. III: 1669-1673, opr. L.A. Wierzbicki, Warszawa 2009 (według indeksu).

Koroljuk V.D., Rogov A.I., Bitva pod Venoj 1683 g. i pussko-pol'skieotnošenija (Dokumenty Posol'skogoprikaza o priezde v Moskvupol'skogoposlannika Jana Okrasy) [w:] Avstro-Vengrija i slavjano-germanskieotnošenija, Moskva 1965, s. 183-199.

Traktaty pokojowe pomiędzy Rzeczapospolita a Rosja w XVII wieku, red. i thum. O. Aleksejczuk, noty o autorach M. Dmitrijew, H. Łaszkiewicz, Kraków 2002.

Volumina Legum, t. 6, Warszawa 1980, s. 73-82.

\section{Opracowania}

Andreev I., Aleksej Michajlovič, Moskva 2006.

Czamańska I., Oswobodziciel czy najeźdźca? Polityka Jana III Sobieskiego wobec hospodarstw Moldawii i Woloszczyzny, „Roczniki Historyczne” 1989-1990, t. 55-56, s. 151177.

Florja B., Izmena Jana Sobeskogo i russko-pol'skieotnošenija. 1667-1672 [w:] Świat pogranicza, red. M. Nagielski, A. Rachuba, S. Górzyński, Warszawa 2003, s. 231235.

Grekov I.B., Meždunarodnoe značenie dogovora meždu Rossiej i Reč’juPospolitoj [w:] Przemiany w Polsce, Rosji, na Ukrainie, Białorusi i Litwie (druga połowa XVII-pierwsza XVIII w.), red. nauk. J. Bardach, Wrocław-Warszawa-Kraków 1991, s. 182-205.

Istorija vnešnej politiki Rossii. XVII vek, Moskva 1999.

Kočegarov K., Początek wojny polsko-tureckiej a stosunki polsko-rosyjskie $w$ pierwszej połowie 1683, „Kwartalnik Historyczny” 2005, R. CXII, nr 1, s. 53-76.

Koczegarow K., Rzeczpospolita a Rosja w latach 1680-1686. Zawarcie traktatu o pokoju wieczystym, Warszawa 2017.

Kulecki M., Wygnańcy ze wschodu. Egzulanci w Rzeczypospolitej w ostatnich latach panowania Jana Kazimierza i za panowania Michała Korybuta Wiśniowieckiego, Warszawa 1997.

Konopczyński W., Dzieje Polski nowożytnej, t. 1-2, Warszawa 2003.

Matwijów M., Ostatnie sejmy przed abdykacja Jana Kazimierza 1667 i 1668, Wrocław 1992.

Nagielski M., Rywalizacja Rzeczypospolitej z Państwem Moskiewskim o dominację w Europie Środkowo-Wschodniej w XVI-XVII w., ,Sensus Historiae” 2013, t. XI, nr 2, s. 87-115.

Soloviov' S.M., Istorija Rossii s drevnejšich vremen [w:] Sočinenija, kn. 6-7, Moskva 1991.

Stolicki J., Wygnańcy ukrainni po traktacie Grzymultowskiego [w:] Spoleczeństwo polskie $i$ wojsko. Studia i materiaty, red. K. Maksymiuk, D. Wereda, A. Zawadzki, Siedlce 2016, s. 71-82. 
Studia z dziejów stosunków Rzeczypospolitej z państwem moskiewskim w XVI-XVII wieku, red. M. Nagielski, K. Bobiatyński, P. Gawron, Zabrze-Tarnowskie Góry 2013.

Wójcik Z., Dyplomacja polska w okresie wojen drugiej połowy XVII wieku (1648-1699) [w:] Historia dyplomacji polskiej, t. 2: 1572-1795, red. Z. Wójcik, opr. J. Gierowski, J. Michalski, H. Wisner, Z. Wójcik, Warszawa 1982, s. 163-330.

Wójcik Z., Dzieje Rosji 1533-1801, Warszawa 1971.

Wójcik Z., Jan Sobieski 1629-1696, Warszawa 1983.

Wójcik Z., Między traktatem andruszowskim a wojna turecką. Stosunki polsko-rosyjskie 1667-1672, Warszawa 1968.

Wójcik Z., Rokowania polsko-rosyjskie o „pokój wieczysty” w Moskwie w roku 1686 [w:] Studia poświęcone pamięci Edwarda hr. Raczyńskiego Prezydenta Rzeczypospolitej Polskiej na wychodźstwie, red. H. Bułhak, Warszawa 1993, s. 38-55.

Wójcik Z., Traktat andruszowski 1667 roku i jego geneza, Warszawa 1959.

Zaborovskij L.V., Velikoe knjažestvo Litovskoe i Rossija vo vremja pol’skogo Potopa (1655-1656 gg.): dokumenty, issledovanija, Moskva 1994.

Zamyslovskij E.E., Snošenija Rossii c Pol'šej v carstvovanije Fedora Aleksejeviča, Sankt-Peterburg 1888. 